Universidade de Brasília

Centro de Excelência em Turismo

\title{
MACHU PICCHU: PATRIMÔNIO HISTÓRICO EMBLEMÁTICO DO TURISMO CULTURAL NA HUMANIDADE
}

Janice Del Frari Coutinho

Monografia apresentada ao Centro de Excelência em Turismo da Universidade de Brasília como requisito parcial para a obtenção do certificado de Especialista em Turismo e Hospitalidade, sob a orientação da Profa. Dra. Dóris Santos de Faria.

Brasília, DF, fevereiro de 2004 


\section{Universidade de Brasília \\ Centro de Excelência em Turismo \\ Curso de Especialização em Turismo e Hospitalidade}

\section{MACHU PICCHU: PATRIMÔNIO HISTÓRICO EMBLEMÁTICO DO TURISMO CULTURAL NA HUMANIDADE}

\section{Janice Del Frari Coutinho}

Banca Examinadora

$\overline{\text { Profa }^{a} \text {. Dra. Dóris Santos de Faria }}$

Brasília, DF, fevereiro de 2004. 
Coutinho, Janice Del Frari

Machu Picchu - Patrimônio Histórico Emblemático do Turismo Cultural na Humanidade / Janice Del Frari Coutinho.

43 folhas.

Monografia (especialização) - Universidade de Brasília. Centro

de Excelência em turismo. Brasília, 2004.

Área de concentração: Turismo

Orientadora: Dra. Dóris Santos de Faria.

1- Turismo: América Latina 2- Patrimônio Cultural do Peru

3- Patrimônio Cultural: Preservação 
Janice Del Frari Coutinho

\section{MACHU PICCHU: PATRIMÔNIO HISTÓRICO EMBLEMÁTICO DO TURISMO CULTURAL NA HUMANIDADE}

Comissão Avaliadora

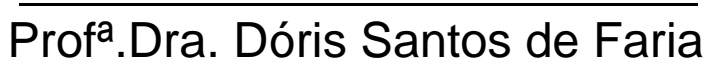

Brasília, DF, fevereiro de 2004 
"Para minha sobrinha Luana " 
Aos meus pais e minhas irmãs que sempre incentivaram o meu crescimento pessoal.

Aos meus chefes pela compreensão e apoio.

Aos meus amigos pelo estímulo e colaboração, principalmente a Lucinda, Solange e Sérgio.

A minha orientadora pela enorme contribuição.

A coordenadora e aos professores do curso, pela dedicação no diaa-dia. 
"Aos olhos que a contemplam pela primeira vez, Machu Picchu é uma fascinante cidade encantada, criada num outro planeta. Milagre de taumaturgos, ela guarda dentro de suas entranhas alguma coisa que ultrapassa a majestosidade do Fórum Romano e do Pathénon de Atenas”

Luis Pardo, 1961. 


\section{Resumo}

O presente trabalho se propõe analisar a ameaça à preservação de um dos mais belos e importantes sítios arqueológicos da humanidade, localizado na América Latina, mais especificamente nos Andes Peruano. Machu Picchu, apesar de tombado pelo Patrimônio Mundial da Humanidade, enfrenta um crescimento desordenado do turismo. O problema é de difícil equacionamento, pois as causas não se devem apenas a ganância de quem explora a atividade turística, mas a necessidade de entrada de divisas para o Governo do Peru e, principalmente, para a geração de emprego em uma região carente de outros serviços produtivos. Os turistas também não são preparados adequadamente para este tipo e local de turismo. Tampouco a pressão predatória que exercem, causando tremor e sujeira, especialmente pelo volume de lixo que deixam no local. Também é analisado o fluxo de turistas do Brasil para aquela localidade, especialmente oriundas de Brasília. O debate da questão se torna fundamental e deve envolver governo, iniciativa privada e sociedade civil a fim de que todos assumam responsabilidades e, juntos, promovam um turismo organizado, garantindo desse modo a sustentabilidade do ambiente local e a preservação desse importante patrimônio histórico e cultural, que termina servindo de exemplo para todas as situações que integrem preservação histórica e turismo cultural.

1.Machu Picchu; 2. Patrimônio Mundial da Humanidade; 3. Governo do Peru 


\begin{abstract}
The present work considers to analyze and to investigate the threat that currently hangs on one of the most beautiful e important archaeological patrimony of the humanity, located in Latin America, more specifically in Peruvian Andes. Machu Picchu although tumbled for the World-wide Patrimony of the Humanity, comes, due to the disordered growth of the tourism, having its threatened preservation. The problem is, without a doubt, of difficult equation, because the cause is not only the greed of who explores the tourist activity, but it implies in the entrance of verge for the Government of Peru and, mainly, in the generation of job for a devoid region of other productive activities. The tourists are also not prepared adequately for this type and place of tourism. Neither the predatory pressure that exerts, causing tremor and dirt,especially for the volume of garbage that they leave in the place. Also the flow of tourist of Brazil for that locality, especially deriving is analyzed of Brasilia. The debate of the question if becomes basic and must involve government, private initiative and civil society so that all assume responsibilities and, together, promotes a tourism organized, guaranteeing in this way the sustentability of the local environment and the preservation of this important historic site and cultural, that finishes serving of example for all the situations that integrate historical preservation and cultural tourism.
\end{abstract}

1. Machu Picchu; 2. World-wide Patrimony of the Humanity; 3. Government of Peru 


\section{SUMÁRIO}

INTRODUÇÃO 01

1 - O PATRIMÔNIO HISTÓRICO DA HUMANIDADE E O TURISMO

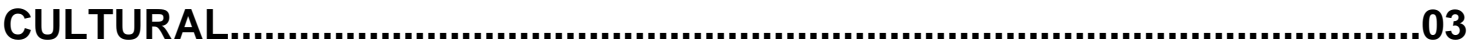

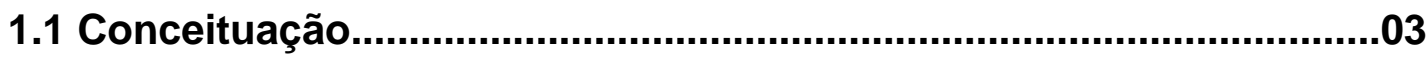

1.2 O Turismo Histórico e Cultural.............................................................09

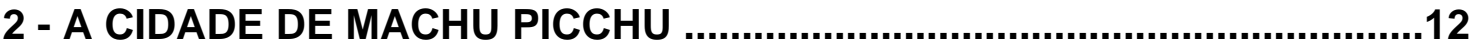

2.1- Localização........................................................................................14

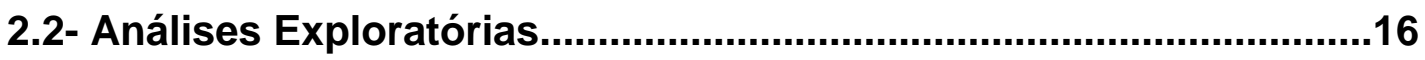

2.3- A ameaça do turismo.........................................................................17

3 - O TURISMO E A PRESERVAÇÃO: COMO UNI-LOS? ..............................22

4 - O TURISMO DE BRASILEIROS EM MACHU PICCHU.............................26

4.1 Estatística de turistas brasileiros e europeus...................................26

4.2 Turistas brasilienses em Machu Picchu.............................................27

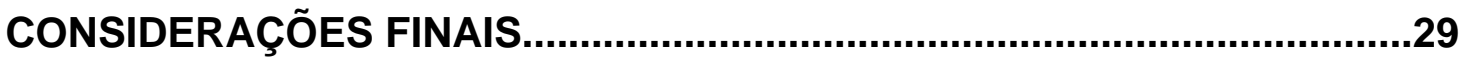

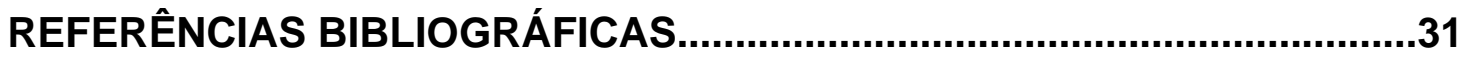

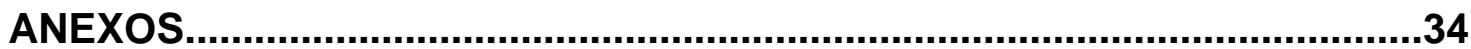




\section{INTRODUÇÃO}

O Turismo, pela sua relevância cultural, social e econômica, deve ser investigado em seus mais diversos aspectos e características. Hoje, é considerado de particular importância pela sua peculiaridade de permitir ao homem contemporâneo a interação com a pluralidade de pensamentos, culturas e realidades de todo o planeta. Dentro da nova configuração social mundial, o Turismo é uma das áreas, em escala local ou global, em que se operam as maiores potencialidades de organização em rede nas sociedades do século XXI.

Pelo seu dinamismo e flexibilidade, o turismo se tornou um fundamental canal de disseminação e divulgação de conhecimentos. Pode ser visto como um setor capaz de catalisar infinitas idéias, costumes e linguagens.

$\mathrm{Na}$ atividade turística de qualquer país ou comunidade podem ser encontrados aspectos positivos e negativos. Como, por exemplo, a grande entrada de capital econômico, como positivo, e a depredação e o risco que correm patrimônios históricos, como negativo.

Diante de tais constatações, verifica-se a dificuldade em conciliar o desenvolvimento econômico que o setor gera a um País com o processo desordenado do turismo e com a preservação de riquezas culturais e históricas, tanto por parte dos governantes como dos habitantes locais.

Pela sua importância estratégica na atualidade, o Turismo deve ser visto como uma responsabilidade de todos - governos, iniciativa privada e sociedade civil. Há o consenso de que, para incrementar e organizar o Turismo, é necessário garantir a sustentabilidade e a preservação de Patrimônios da Humanidade.

Esse é o objetivo do presente estudo. Analisar a ameaça do turismo desordenado à preservação de Machu Picchu, um dos mais belos sítios arqueológicos do mundo, tombado pelo Patrimônio Cultural da Humanidade.

O estudo tem como fundamentação teórica, a relação entre sustentabilidade e preservação, nexos buscados na bibliografia de suporte. 
A base empírica foi constituída de consultas em páginas eletrônicas especializadas, revistas, jornais e outros impressos. Também servem de subsídio para o estudo, entrevistas com especialistas e verificação in loco feita recentemente por esta pesquisadora.

Os estudo está apresentado em quatro capítulos seguidos das considerações finais. O primeiro se refere à conceituação de Patrimônio Histórico, a contextualização da preservação dos patrimônios em âmbito mundial e ao estudo sobre o surgimento do turismo cultural e histórico.

O segundo capítulo analisa uma apreciação de Machu Picchu quanto aos seus aspectos físicos, a sua importância como um sítio arqueológico para o Patrimônio Histórico da Humanidade, a constatação de ser um pólo de atração para o turismo cultural e o seu valor econômico para o Peru.

No terceiro capítulo, o enfoque é a união do turismo com a preservação e o quarto capítulo investiga o número de brasileiros que visitam anualmente Machu Picchu, com algum enfoque nos moradores da capital da República.

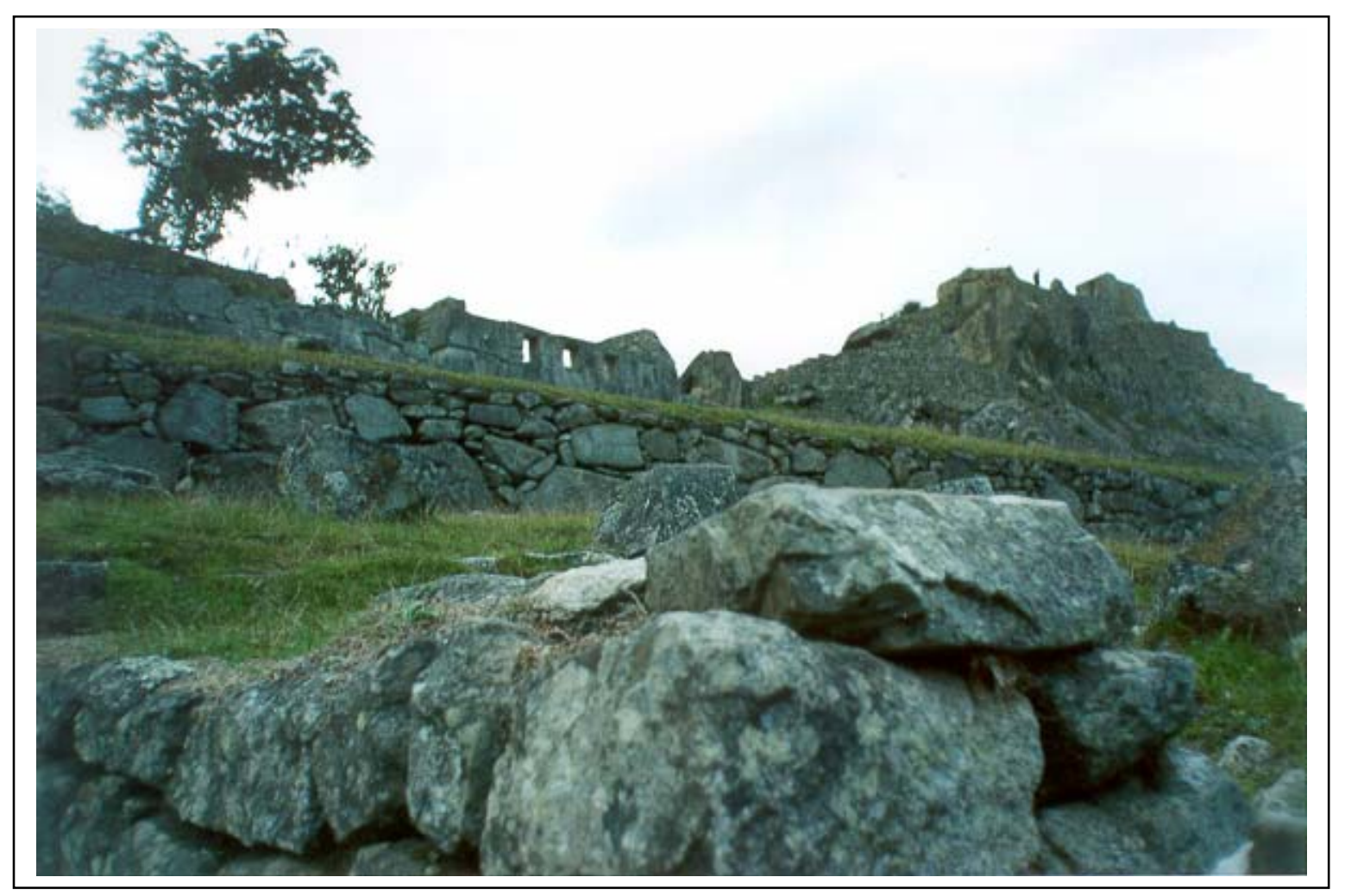

Fonte : Fotografia de Machu Picchu, tirada pela autora em outubro ultimo ( Coutinho 2003 ). 


\section{1 - O PATRIMÔNIO HISTÓRICO DA HUMANIDADE E O TURISMO CULTURAL}

\subsection{Conceituação}

O patrimônio é uma bela e antiga palavra que, em sua origem, esteve ligada às estruturas familiares, econômicas e jurídicas de uma sociedade enraizada no tempo e no espaço. Requalificada por diversos adjetivos (genético, natural, histórico, etc), que fizeram dela um conceito nômade, segue hoje uma trajetória diferente.

Designa um bem destinado ao usufruto de uma comunidade, constituído pela acumulação contínua de uma diversidade de objetos que se congregam por seu passado comum: obras e obras-primas das belas artes e das artes aplicadas, trabalhos e produtos de todos os saberes e savoir-faire dos seres humanos.

Em uma sociedade mutante, constantemente transformada pela mobilidade, a noção de patrimônio remete a uma instituição e uma mentalidade. A institucionalização do patrimônio nasce com a visão moderna de história e de cidade. É na época das Luzes que o patrimônio histórico, constituído pelas antiguidades, tem uma renovação iconográfica e conceitual.

A idéia de um patrimônio comum a um grupo social, definidor de sua identidade e enquanto tal merecedor de proteção, perfaz-se através de práticas que ampliaram o círculo dos colecionadores e apreciadores de antiguidades e se abriram a novas camadas sociais: exposições, vendas públicas, edição de catálogos das grandes vendas e das coleções particulares.

Um dos primeiros atos jurídicos da Constituinte francesa de 02 de outubro de 1789 foi colocar os bens do clero "à disposição da nação". Vieram em seguida os dos emigrados, depois os da Coroa. Assim, a idéia de nação veio garantir o estatuto ideológico do patrimônio e foi o Estado nacional que assegurou, por meio de práticas específicas, a sua preservação.

O surgimento das idéias de direitos dos cidadãos, de representação, de república democrática foram o fundamento para a mudança conceitual do patrimônio, que se inseriu em um projeto mais amplo de construção de uma 
identidade nacional e passou a servir ao processo de consolidação dos estados nação modernos.

Inicialmente, a categoria do patrimônio que mereceu a atenção foi a que se relacionou mais diretamente com a vida de todos - histórico, representado pelas edificações e objetos de arte. Paulatinamente, ocorre a passagem da noção de patrimônio histórico para a de patrimônio cultural, de tal modo que uma visão inicial reducionista, que enfatizava a noção do patrimônio nos aspectos históricos consagrados por uma historiografia oficial, foi-se projetando até uma nova perspectiva mais ampla que incluiu o "cultural", incorporando ao "histórico" as dimensões testemunhais do cotidiano e os feitos não-tangíveis.

No âmbito internacional, durante as últimas décadas, delinearam-se uma série de instrumentos jurídicos, convenções, declarações, resoluções e recomendações relativas à proteção do patrimônio histórico, de tal maneira que as convenções e recomendações aprovadas pela Organização das Nações Unidas para a Educação, Ciência e Cultura (Unesco) vêm a enriquecer o Direito Internacional da Cultura e os direitos internos com a elaboração de leis próprias no sentido dado pela Unesco.

A América do Sul possui um rico e diversificado patrimônio que sintetiza a contribuição de múltiplas culturas originárias do próprio continente ou para aqui transplantadas, de diferentes partes do mundo. Estas características estão reconhecidas no texto constitucional, que adota um conceito amplo de patrimônio histórico. Bem diferente da visão tradicional e elitista que resumia o patrimônio quase exclusivamente à arquitetura, igrejas, fachadas de prédios, marcada por um caráter monumental.

Esta concepção contemporânea de patrimônio histórico resulta de processo de mudanças sócio-culturais. Entre elas destacam-se o aumento da pressão social no sentido da preservação; a necessidade da participação da comunidade neste sentido; a preocupação com a sua revitalização apresentando interfaces significativas com outros importantes segmentos como o do turismo e da economia em geral; finalmente, a tomada de consciência que preservar 
corresponde à melhoria da qualidade de vida e fundamento para se alcançar o desenvolvimento sustentável (Arantes, 2000, p. 118).

Conforme Arantes (2000, p. 204), desde 1937, a América do Sul vem desenvolvendo uma política específica para a identificação e preservação dos bens históricos. No Brasil, por exemplo, para protegê-los foram criadas instituições a nível federal, como o Instituto de Defesa do Patrimônio Histórico e Artístico Nacional (IPHAN), a nível estadual e municipal. Hoje se acrescentam as iniciativas de Organizações Não-Governamentais (ONG's), com muita atuação nestas questões. É preciso salientar o avanço verificado em todo o mundo no que se refere ao apoio dado por organismos internacionais, como a Unesco.

Dentre os resultados tem-se a criação de leis de proteção e do instituto legal do tombamento. Pode-se acompanhar a desenvolvimento de inúmeros projetos para a salvaguarda do patrimônio histórico tanto a nível nacional, como mundial.

A política de preservação emanada do Estado, com uma visão paternalista e elitista, aos poucos vai se alterando, no sentido de criar canais de participação efetiva dos membros da comunidade, sendo que grandes campanhas de preservação são montadas e desenvolvidas.

Deve a cada dia crescer a convicção da necessidade da participação de cada comunidade na salvaguarda de seus bens, integrando os membros da sociedade, como forma eficaz de garantir a continuidade de projetos desta natureza. A comunidade deve se transformar na verdadeira responsável e guardiã de seus bens históricos. Pois, foi ela quem as produziu. Portanto, não se pode pensar em preservar senão no interesse da própria comunidade, à qual compete tomar as decisões, no exercício pleno de sua autonomia e cidadania.

Conforme Castro (1991, p. 97), a preservação do bem histórico vincula-se à sua correta utilização e integração no cotidiano da comunidade. A atuação do poder público deve ser exercida em caráter excepcional para subsidiar em nível de conhecimentos, na educação formal e informal, visando desenvolver o sentimento de valorização dos bens culturais, com recursos técnicos, financeiros ou materiais, ou ainda na orientação das organizações coletivas. 
A atuação neste setor se integra com as questões sócio-econômicas, técnicas, artísticas e ambientais, articulando-as com as questões da cidadania e da qualidade de vida.

O patrimônio histórico tem um significado especial para muitas localidades, por sua paisagem urbana e natural. Pode ainda se transformar em importante fonte de receitas derivada do turismo. Com as leis de incentivo histórico/cultural existentes, é possível recuperar edifícios, preservar monumentos e cidades, aumentando postos de trabalho e recursos para a comunidade. Uma política preservacionista pode garantir a recuperação de áreas degradadas, fazendo aumentar o valor das propriedades localizadas nessas delimitações e, ainda, melhorar o desempenho econômico da região, com a conseqüente dinamização da economia da localidade.

Para Castro (1991, p. 179), o bem histórico é dotado de valor social. Ele tem a capacidade de estimular a memória das pessoas, vinculado a uma comunidade, contribuindo assim para garantir a sua identidade cultural e melhorar a sua qualidade de vida. Agir no sentido de preservar os bens históricos significa construir uma importante ponte para a garantia do desenvolvimento sustentável dos povos.

Conforme Santos, não se entenda por preservação apenas o ato do tombamento. Preservar é conservar a memória. Portanto, conceito genérico que dá ao Poder Público o direito de, conforme a legislação, exercer todas as atividades administrativas indispensáveis ao fomento de ações de preservação, sem ferir direitos individuais.

De acordo com Chauí (2002, p. 88), é preciso manter viva a história de um país. Por isso, o tombamento se justifica para os bens, cuja conservação seja de interesse público, quer por seu excepcional valor arqueológico, etnográfico, bibliográfico ou artístico, quer por sua referência a fatos e valores históricos.

A preservação de patrimônio histórico faz-se indispensável. Proporciona a manutenção dos testemunhos das manifestações culturais e ambientais que possibilitam a uma sociedade reconhecer a sua identidade, valorizando-a e estabelecendo referencias para a construção de seu futuro. Essa identidade está 
relacionada com uma historicidade, uma cultura formada nos hábitos de uma comunidade, em lugares que levam a marca dos povos, nos prédios, na casas, nas praças, nas ruas.

Segundo Halbwachs (1990, p.34):

"... quando um grupo humano vive muito tempo em lugar adaptado a seus hábitos, não somente os seus movimentos, mas também seus pensamentos se regulam pela sucessão das imagens que lhe representam os objetos exteriores... Certamente é inevitável que as transformações de uma cidade e a simples demolição de uma casa incomodem alguns indivíduos em seus hábitos, perturbem-nos e os desconcertem (...) Um outro habitante, para quem esses velhos muros, essas ruas sem saída, faziam parte de seu pequeno universo, e cujas lembranças se ligam a essas imagens, agora apagadas para sempre, sente que toda uma parte de sei mesmo está morta com essas coisas e lamenta que elas não tenham durado, pelo menos tanto tempo quanto Ihe resta viver".

De acordo com Lemos (1985, p.8), o patrimônio histórico é o acervo maior de uma nação ou de um povo e abrange todo o elenco de bens denominados históricos e culturais. O motivo é que "entre todos eles qualquer que seja o atributo que se lhe der existe forte travamento das relações estabelecidas".

Lemos (1985, p.9) cita Hugues de Varine-Bohan para dividir o patrimônio histórico e cultural em três grandes categorias de elementos.

A primeira arrola os elementos pertencentes à natureza, ao meio ambiente. São recursos naturais, que tornam o sítio habitável. Nesta categoria estão os rios, as águas, os peixes, etc.

O segundo grupo de elementos refere-se ao conhecimento, as técnicas, ao saber e ao saber fazer. São os elementos tangíveis do Patrimônio Cultural compreendendo toda a capacidade de sobrevivência do homem no meio ambiente. Vai desde a perícia do rastejamento de uma caça esquiva em uma floresta para a alimentação até a elaboração matemáticas e a computadores de ultima geração.

O terceiro são os chamados de bens culturais, que englobam objetos, artefatos, edificações e construções, entre outros. De acordo com o autor, a 
palavra artefato deveria ser a única empregada no caso, tanto no que se refere a machados, mesa e móveis históricos até igrejas, casarões, etc.

Como conceito ainda se tem os estudos da Organização das Nações Unidas para a Educação, a Ciência e a Cultura (Unesco) ${ }^{1}$ onde a palavra patrimônio tem vários significados. O mais comum é o conjunto de bens que uma pessoa ou uma entidade possuem. Transportado a um determinado território, o patrimônio passa a ser o conjunto de bens que estão dentro de seus limites de competência administrativa. Assim, patrimônio nacional, por exemplo, é o conjunto de bens que pertencem a determinado país. Independentemente do corte territorial, que implica a delimitação do patrimônio dentro de fronteiras geopolíticas, há outros cortes pelos quais o patrimônio pode ser analisado.

O patrimônio pode ser classificado por duas grandes divisões: natureza e cultura. Patrimônio natural são as riquezas que estão no solo e no subsolo, tanto as florestas quanto jazidas. O conceito de patrimônio cultural vem sendo ampliado à medida que se revisa o conceito de cultura. Atualmente, há consenso de que a noção de patrimônio cultural é muito mais ampla. Não inclui apenas os bens tangíveis, como também os intangíveis, não só as manifestações artísticas, mas todo o fazer humano, e não só aquilo que representa a cultura das classes mais abastadas, mas o que representa a cultura dos menos favorecidos.

Nesse sentido, o patrimônio deixou de ser definido pelos prédios que abrigaram reis, condes e marqueses e pelos utensílios a eles pertencentes. Passou a ser definido como o conjunto de todos os utensílios, hábitos, usos e costumes, crenças e forma de vida cotidiana de todos os segmentos que compuseram e compõem a sociedade ao longo dos anos.

No século $X X$ a sensação da fragmentação da identidade, da perda das referências culturais, despertou no homem o desejo de "retorno a algo perdido", ou seja, a necessidade de buscar manifestações culturais que pertencem a seu passado vivo, a comportamentos que deixaram de ser comuns, pois o "frenesi" contemporâneo exige atitudes da sociedade globalizada.

\footnotetext{
${ }^{1}$ Unesco: 2003. Bo, Proteção do Patrimônio.
} 
Desta forma, surge o turismo cultural e histórico, onde os indivíduos passam a buscar viagens e suas formas diferenciadas para ter contato com civilizações antigas, símbolos e ambientes históricos que integram a história da humanidade. Esse tipo de turismo permite, ainda, que o individuo reflita sobre o seu próprio passado e dos povos que habitaram os mais diferentes lugares, nas mais diversificadas situações.

\subsection{O Turismo Histórico e Cultural}

A manutenção e a revitalização dos centros históricos é relativamente recente, tanto no panorama mundial, quanto no âmbito brasileiro. A preservação de áreas urbanas degradadas de valor histórico-cultural tem sido foco de atenção, por parte dos agentes governamentais, nas experiências urbanísticas mais recentes no campo internacional. Essas experiências têm proporcionado soluções amplas, seja nos níveis e padrões de intervenção, seja nos modelos e estratégias de gestão adotados para enfrentar o problema da preservação sustentável do patrimônio cultural urbano.

Para que a preservação do patrimônio histórico seja eficaz, deve-se primeiramente encontrar uma solução para o que fazer com esses centros históricos. Para uma edificação isolada é fácil encontrar uma utilização adequada, como um museu.

No entanto, para um conjunto de um acervo edificado, como por exemplo, da área do Pelourinho, em Salvador (Bahia), e de Machu Picchu, no Peru, é necessária a preservação e a readaptação do uso habitacional e turístico. A manutenção de uma área preservada (Teles, 1984, p. 29-32) e a sua sustentabilidade devem ser responsabilidade de todos - governantes, turistas e população local.

O turismo histórico/cultural é a atividade que melhor utiliza as potencialidades da preservação do patrimônio histórico, criando comprometimento e envolvimento de todos os segmentos da população, oferecendo vantagens 
econômicas e sociais, principalmente sob a forma de geração de empregos e renda.

Contudo, é fundamental a parceria entre Estado e iniciativa privada para a atuação e a elaboração de planos e estratégias para o turismo, a fim de evitar que se crie um ambiente de exploração econômica abusiva na região.

Neste contexto, surge uma pergunta que pode deixar o termo referido como um pleonasmo. Se a história está presente nas destinações visitadas e os turistas estão em contato com ela, podemos dizer que todas as modalidades de turismo são históricas? De certa forma sim. Entretanto, o termo turismo histórico, existe para classificar os indivíduos que se deslocam com objetivos principais de conhecer diversas ou especificamente algumas manifestações históricas e culturais de uma localidade, sejam materiais e/ou imateriais.

Como afirma Telles (1984, p, 18), o turismo que vive, principalmente do patrimônio histórico e cultural, passa pelo dilema da preservação. De um lado, a vertente tradicional do turismo de massa pode ter efeitos devastadores sobre a cultura, a ecologia e a história de um lugar, como se nota em vários lugares de intensa visitação. Por outro lado, o turismo sob formas mais calmas e alternativas, como as diferentes modalidades de turismo cultural e histórico, é hoje visto como um catalisador do desenvolvimento sustentável, capaz de dinamizar economias locais, preservando ao mesmo tempo a cultura e a história local.

Soares (2003) mostra que, durante os anos 70, começou-se a criticar o impacto negativo do turismo de massas sobre o meio ambiente e locais denominados patrimônio da humanidade. Apontou-se a devastação de áreas naturais, como parques e zonas costeiras, até o comprometimento da qualidade de vida dos centros históricos das cidades, causada pelo intenso trânsito, todo o tipo de poluição e danos, aumento da violência e crescimento desordenado da periferia. 
Já nos anos 80 o enfoque foi a necessidade de desenvolver formas alternativas de turismo, através de uma abordagem holística da atividade, de forma a beneficiar visitantes e visitados. O hemisfério norte investiu muito em suas cidades turísticas, na diversificação de seus atrativos, na interpretação e apresentação de seu patrimônio. No entanto, não houve um planejamento com a parceria entre órgãos de preservação e turismo, com o efetivo envolvimento da população e de suas práticas culturais, que foram, em muitos casos, excluídos e pasteurizados para o rápido consumo turístico.

O resultado deste fenômeno pode ser visto ainda hoje quando se passeia por algumas cidades européias, por exemplo, onde se tem a impressão do déjà $v u$, tal a mesmice de certas paisagens urbanas, esvaziadas de conteúdo sóciocultural, meros cenários de filme ou shopping centers ao ar livre, com decoração e mobiliário semelhante e lojas sempre iguais, a celebração do não-lugar no cenário global. O prazer da visita é comprometido, aqui e lá, por razões distintas, sendo o denominador comum a concentração de gente e barulho.

Nesse contexto começa a se vislumbrar a necessidade de uma análise mais concreta de um local que tem se tornado foco de muitas viagens dos brasileiros e de outras pessoas de diferentes nacionalidades: a cidade inca de Machu Picchu.

De acordo com Motta (2002, p.22), a cidade é um dos pólos mais visitados em se tratando de turismo histórico/cultural da América Latina e talvez até do mundo. Mas será que esta intensa visitação não estaria destruindo um dos maiores berços de uma civilização? Será que a intensa visitação e as iniciativas de turismo naquele local não estão colocando em risco a memória da história da humanidade? O turismo direcionado a Machu Picchu tem uma sustentabilidade local que oferece vantagens econômicas e sociais que se sobrepõe ao desgaste provocado pelas visitações? 


\section{2 - A CIDADE DE MACHU PICCHU: PATRIMÔNIO HISTÓRICO DA HUMANIDADE}

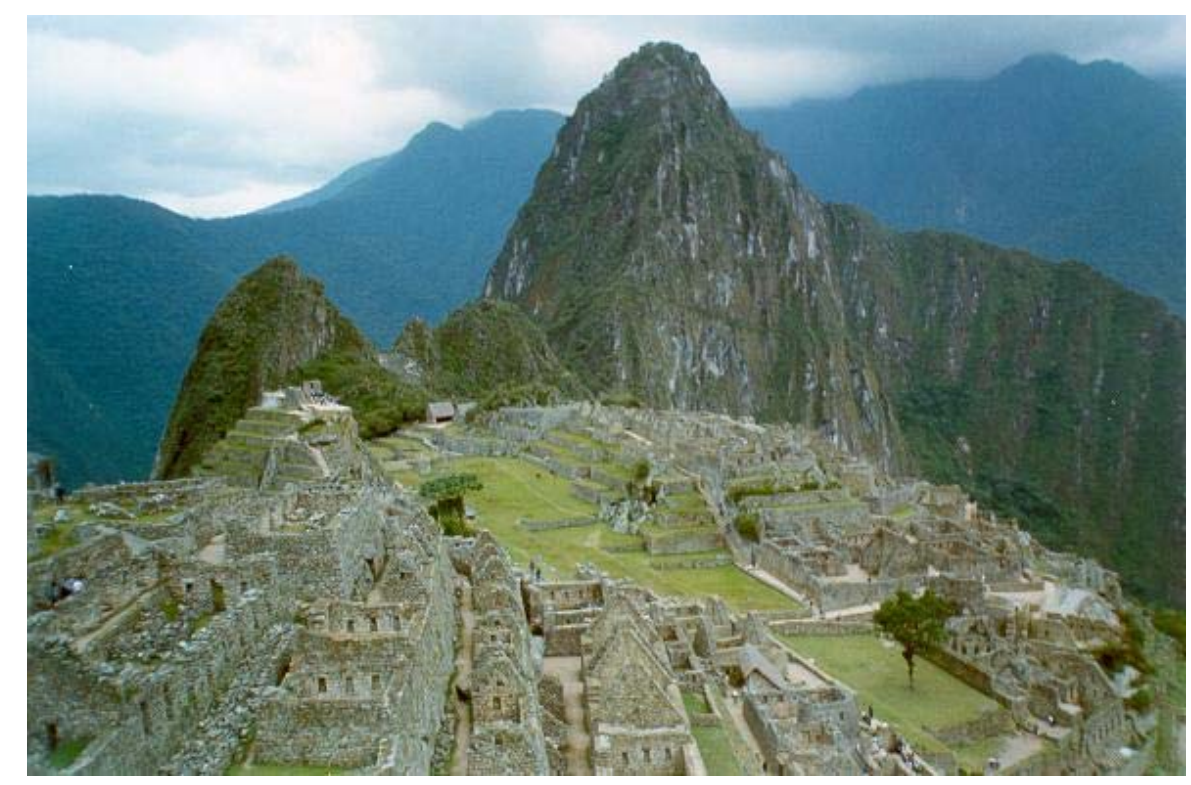

Fonte: Fotografia de Machu Picchu, tirada pela autora em outubro ultimo ( Coutinho 2003).

Segundo Canes (2002), Machu Picchu ou "Velho Pico" foi descoberto, oficialmente, no dia 24 de Julho de 1911, pelo historiador americano Hiram Bingham, que patrocinado pela Universidade de Yale e a National Geographic Society, fazia pesquisas no Peru. Na ocasião, buscava uma outra cidade perdida chamada "Vilcabamba", que teria sido o último esconderijo do imperador inca, antes da conquista pelos espanhóis. Acompanhado por dois camponeses, a quem pagou 1 sol (moeda peruana), queria conhecer as "ruínas dos índios". A cidade foi encontrada totalmente abandonada e encoberta pela selva. Estima-se que tenha ficado escondida por 3 séculos, sendo que da primeira expedição trouxeram vasos, armas incas, tecidos, ornamentos e 12 mil fotos.

Machu Picchu possui um setor agrícola separado da área urbana por uma espécie de fosso seco que aproveita uma falha geológica do terreno e a divide no sentido longitudinal, sendo uma grande área de terraços, tanto para plantio de batata e outros tubérculos, quanto para impedir a erosão das encostas, e que era mais do que suficiente para torná-la autônoma em termos de alimentação. 
Também havia sistemas de irrigação, como aquedutos que traziam água das montanhas.

O citado setor urbano, incluindo templos, praças, centros de estudo astronômicos e outras áreas, apresenta mais ou menos 200 habitações, que deviam abrigar em torno de 400 pessoas. Existem também moradias de maior e menor porte que, possivelmente, eram destinadas aos altos dignatários, 0 chamado setor industrial parece ter sido a área dedicada ao beneficiamento de grãos e produtos de origem animal, pelo tipo de construções que apresenta.

A cidade de Machu Picchu possui uma grande quantidade de templos, reconhecidos pela qualidade das obras e pelo acabamento rebuscado. Em um dos templos, com três janelas de formato trapeizodal, há uma laje ostentando um entalhe com o motivo da cruz escaliforme, mesmo desenho que se vê em Ollantaytambo (Peru) e nas ruínas de Tihuanaco, na Bolívia (Motta, 2002, p. 107).

Na opinião de Riberi (2000), o santuário que mais se destaca dentre todos os santuários da cidade, é o Intihuatana ou "Poste de Amarrar o Sol", sendo que sua função era relacionada com as observações astronômicas e cálculos dos solstícios e equinócios.

Soares (1998, p. 305) mostra que, dentre vários outros exemplos, a tese de que os incas eram astrônomos hábeis ganha força quando se conhecem os espelhos d'água usados para observar o céu sem ficar com torcicolo e, principalmente, o Templo do Sol, que embora pequeno em sua construção, guarda uma espetacular grandeza de cálculo. Às 7 h15 do dia 21 de junho, solstício de inverno, os primeiros raios de sol, com precisão digital, antes de iluminar qualquer outra parte da cidade, se voltam para a única janela do Templo.

Dessa forma, constata-se que Machu Picchu abriga muitas proezas, até no que se refere à sua capacidade de vencer a ação do tempo. Todas as pedras da cidade são originais e $60 \%$ delas estão intactas, tendo resistido a pelo menos dois grandes terremotos, o de 1650 e o de 1950. 
Para Cannes (2002, p. 94), um exemplo da importância histórica de Machu Picchu está em seus milhares de achados, entre eles 164 restos de corpos mumificados (102 de mulheres adultas; 22 de homens adultos; 11 de jovens, sendo 7 femininos e 4 masculinos; 5 de crianças; e 24 de sexo desconhecido, sendo 17 de adultos e 7 de adolescentes). Alguns foram encontrados com 0 crânio perfurado, indicando que os incas conheciam rudimentos de cirurgias cerebrais.

Para esta cidade, existem muitas lendas sobre sua função e quem realmente a habitava. Entre elas, uma que diz que a cidade teria sido habitada por sacerdotisas, bruxas e feiticeiras, temidas pela comunidade por causa dos poderes sobrenaturais, que teriam sido exterminadas por uma catástrofe natural que, para época, era identificada como sobrenatural. Conta-se que uma violenta tempestade teria castigado o local e os raios, atraídos pelos metais, foram interpretados como o presságio de que a cidade dos deuses deveria ser abandonada e condenada como maldita.

Verifica-se, portanto, que são muitos os mitos que atraem milhares de turistas todos os anos à cidade perdida, ao ponto de se supor que se o número de visitantes não for limitado, em algumas décadas somente sobraram as lendas sobre o local.

\subsection{Localização}

A cidade inca de Machu Picchu está localizada no Peru. O país encontrase na parte oeste da América do Sul e faz divisa com o Chile (sul), Bolívia (sudeste), Brasil (nordeste), Colômbia (norte) e Equador (noroeste). Dividi-se em três regiões principais: uma fina área de costas, composta predominantemente por desertos, contendo as maiores cidades do país e a melhor estrada, a Carretera Panamericana; a larga área Andina, composta da Cordilheira Ocidental e Oriental e incluí Huascarán (6768 mt), a montanha mais alta do país; e a Amazônia, onde se tem a Amazônia peruana, uma região de terras baixas, irrigada principalmente pelos rios Maranon e Ucayali. 


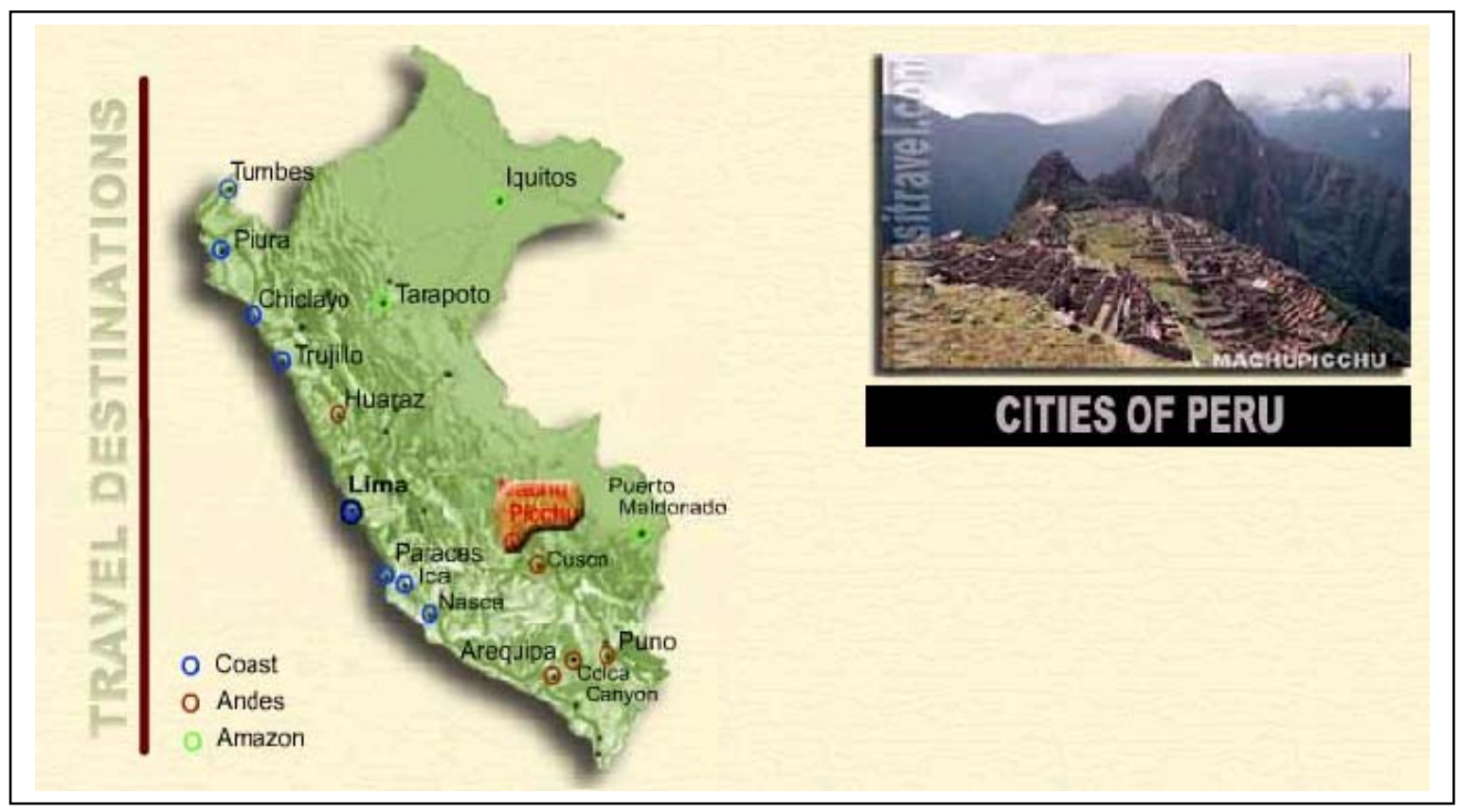

Fonte : Mapa do Peru, disponível na internet em < http://www.masitravel.com/destinos/destinos.htm > , acesso em: Dezembro 2003.

O clima no Peru pode ser dividido em duas estações - a de chuva e a de seca - apesar de haver variação dependendo da posição geográfica. Nas costas e região andina chove pouco, e o verão se estende de dezembro a abril. Durante o resto do ano, a garuá (neblina) é freqüente e o sol raramente sai. A temporada de seca na região dos Andes é entre os meses de maio a setembro, enquanto que o resto do ano é temporada de chuvas.

A cidade de Machu Picchu fica a 2.430m acima do nível do mar, cercada por duas montanhas - Machu Picchu (A Montanha Velha onde está localizada) e Huayna Picchu (a Montanha Jovem, ao norte, com 2.700m), numa região da Cordilheira dos Andes onde começa a Floresta Amazônica Peruana.

Machu Picchu é considerada Patrimônio Cultural da Humanidade. Está localizada nos limites do "Santuário Histórico de Machu Picchu", unidade de conservação criada pelo Governo Peruano, em 1981, com a finalidade de preservar os recursos naturais e culturais de grande valor científico e histórico. Pertence ao distrito de Machu Picchu, província de Urubamba, departamento de Cuzco. 


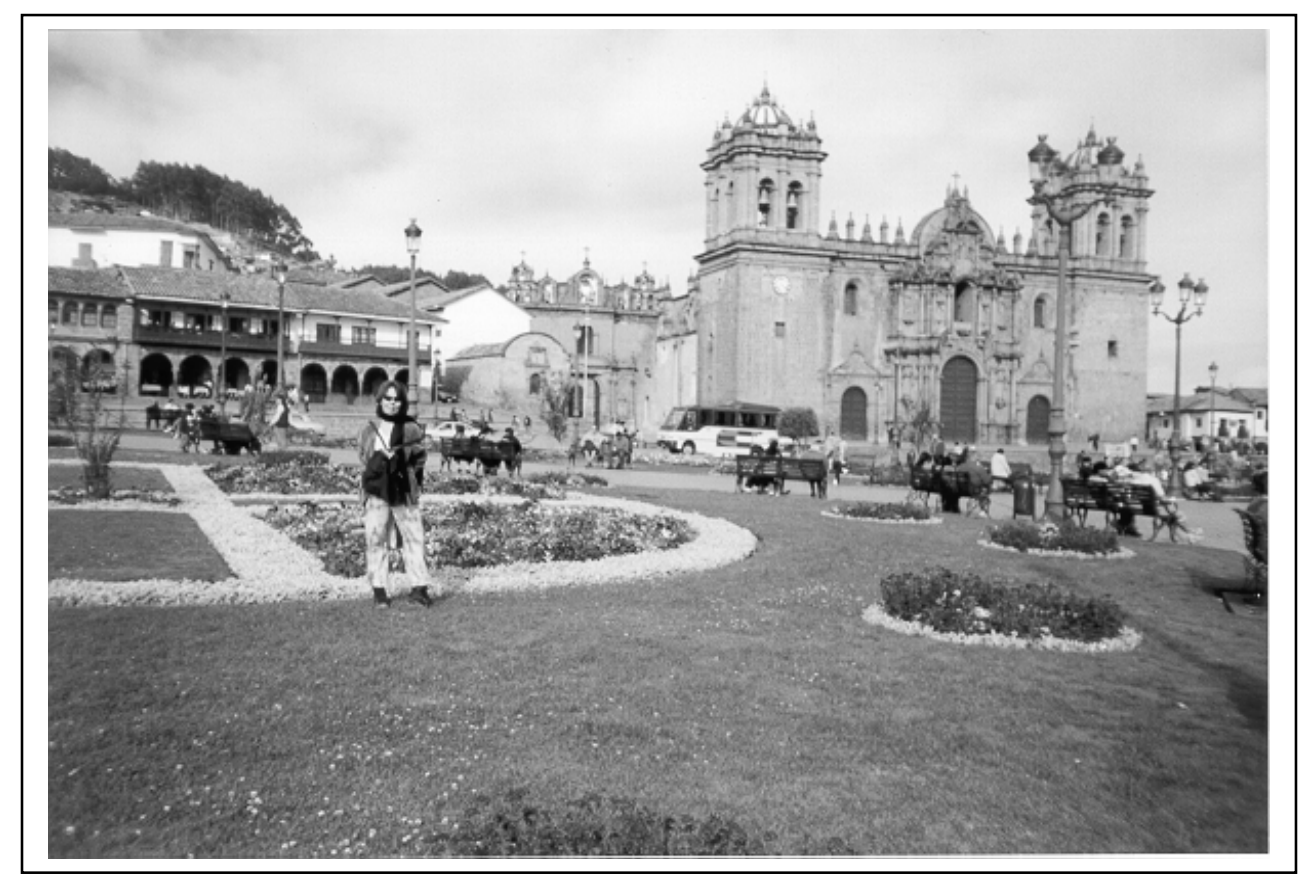

Fonte: Fotografia de Plaza de Armas, em Cuzco. Tirada pela autora em outubro ultimo ( Coutinho 2003).

Machu Picchu fica a 112 km de Cuzco, considerada capital arqueológica da América do Sul, que possui em torno de 300.000 habitantes e está a 3326 metros acima do nível do mar. Tem uma excelente infra-estrutura voltada para o turismo (possivelmente a melhor do Peru), com hotéis, restaurantes e serviços que atendem aos milhares de turistas que a visitam, vindos de todas as partes do planeta $^{2}$.

\subsection{Análises Exploratórias}

A palavra Machu Picchu significa montanha velha, em quechua. A cidade tem um imensurável valor arqueológico. Em 1983, o "Santuário histórico de Machu Picchu" foi declarado pela Unesco, Patrimônio Cultural e Natural da Humanidade. Uma enorme riqueza cultural, histórica e natural dos povos andinos e dos peruanos.

\footnotetext{
${ }^{2}$ CEZARE, Vilma. Machu Picchu - A cidade Perdida. Disponível em www.machupiccuanalise.net/ecoturimo.html. Acesso em 22 jan 2004.
} 


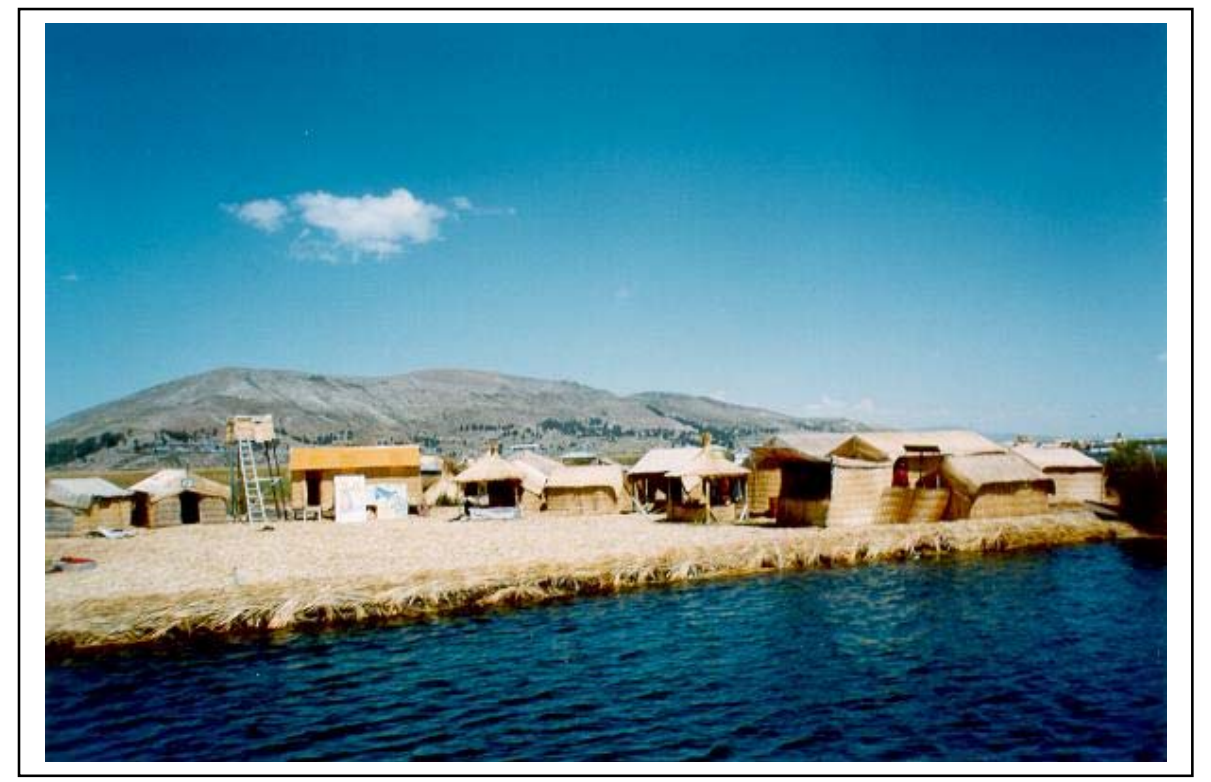

Fonte: Fotografia do lago de Titicaca. Tirada pela autora em outubro ultimo ( Coutinho 2003).

Conforme a lenda a capital do Império Inca ${ }^{3}$, Cuzco, foi fundada por Manco Cápac y Mama Ocllo, filhos do deus Sol, que saíram do Lago Titicaca com a missão de buscar um lugar que fosse o centro de um grande reinado. Já sobre Machu Picchu, numa visão menos "lúdica", há suposições de que tenha sido criada para conquistar a floresta ou proteger o império de quem viesse dela, isso no século XV e sua construção se atribui ao inca Pachacutec.

\subsection{A ameaça do Turismo}

Cada vez mais turistas estão se deslocando para o Peru com o objetivo de chegar à cidade inca de Machu Picchu, preferindo muitas vezes se aventurar e fazer a viagem a pé, por 48 quilômetros de caminhos que cortam a cordilheira e atravessam maravilhosos vales tropicais. Durante o trajeto, conhecido como Caminho do Inca, que dura quatro dias e três noites, os visitantes flanqueiam abismos e cruzam um canyon por meio de uma ponte para chegarem até as ruínas de Machu Picchu, descobertas em 1911.

\footnotetext{
${ }^{3}$ CEZARE, Vilma. A cidade Perdida. Disponível em http://www.machupiccuanalise.net/]ecoturimo.html
} 
Como mostra Riberi (2002), Machu Picchu, com cerca de 32 mil hectares, é um santuário arqueológico e o local de turismo ecológico e histórico mais conhecido e atraente do país. Nota-se que a região concentra uma grande biodiversidade e, embora a maioria dos viajantes o ignore, os vales e as ladeiras do Caminho do Inca contêm cerca de 350 variedades de orquídeas.

Porém, o grande número de turistas deixa sete toneladas diárias de lixo, em sua maior parte de objetos não-biodegradáveis, como garrafas de plástico e, em alguns casos, provocaram incêndios. Ainda ocorrem pichações e depredações a monumentos históricos da própria Machu Picchu. No período de alta temporada, visitam a cidade até $2 \mathrm{mil}^{4}$.

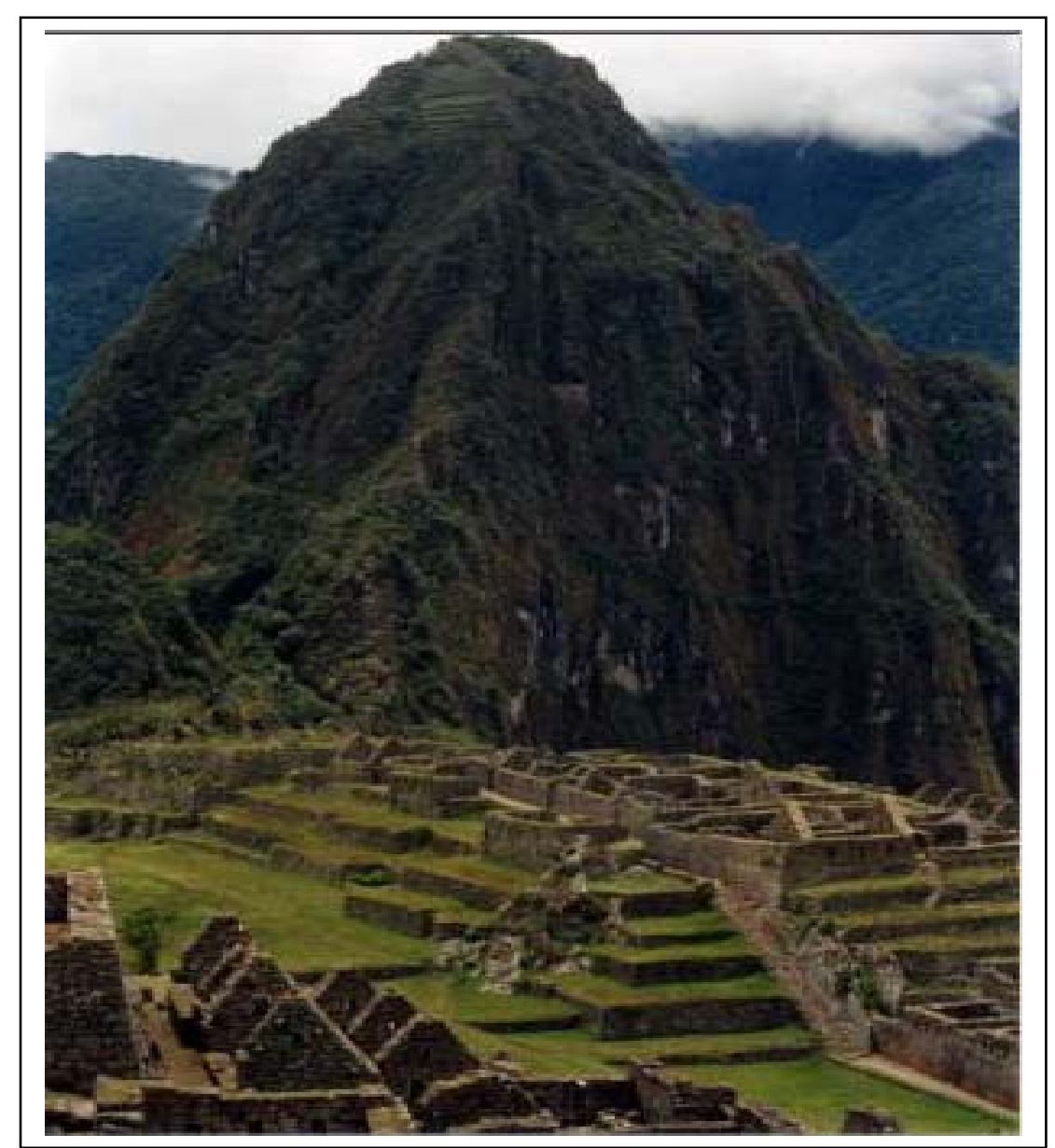

Fonte : Fotografia da Montanha Waynapicchu, tirada pela autora em outubro ultimo ( Coutinho 2003 ).

Para a Unesco, o número adequado de turistas/dia a Machu Picchu deve ser de, no máximo, 800 pessoas $^{5}$. Deverro (2003) alerta que os turistas sobem

\footnotetext{
${ }^{4}$ Dado extraído da página eletrônica da Embaixada Peru. Disponível http://www.embperu

${ }^{5}$ Dado extraído da página eletrônica
} 
nas construções sem se importar com os possíveis danos que tal atitude causa no patrimônio. As arquiteturas rústicas da cidade sobrevivem a séculos de ações da natureza, o que demonstra que não a natureza a principal responsável pela deterioração do local.

O governo local e instituições preocupadas com a preservação de patrimônios históricos da humanidade, como é o caso de Machu Picchu, divulgam diversas campanhas e novas regras para diminuir o impacto da presença humana na referida cidade.

A iniciativa mais importante é a elaboração do Regulamento de Uso Turístico da Rede de Caminhos do Inca do Santuário Histórico de Machu Picchu, realizada pela Unesco, em $2001^{6}$, recomendando o máximo de 500 pessoas simultaneamente na trilha inca. Em alta temporada, o número de visitantes já chegou a 1.200 pessoas simultaneamente.

Em outro item do referido regulamento, há a sugestão de que os grupos de caminhantes não podem ser superior a 40 pessoas, incluindo os guias e os carregadores de barracas, alimentos e combustível. Os caminhos são fechados durante um mês por ano, para restauração dos desgastes ocorridos pelas caminhada de tantos visitantes.

O mesmo regulamento recomenda a proibição do uso de lenha para cozinhar ou esquentar alimentos. Deve utilizar apenas gás de cozinha. A Unesco aconselha aos carregadores levar, no máximo, 25 quilos cada um, e transportar até o final da viagem embalagens para depositar todo o tipo de lixo.

Por enquanto, as recomendações da Unesco ao governo do Peru ainda não saíram do papel. O organismo nem ao menos obteve uma resposta oficial do governo peruano sobre o estudo e sobre a solicitação imediata na redução do número de turistas. A quantidade de visitantes continua descontrolada.

Segundo Silva ( 2001), atualmente, se exige que os turistas devam estar sob os cuidados de agências autorizadas, com pessoal qualificado e treinado e os

\footnotetext{
${ }^{6}$ DEVERRO, Paulo. A ameaça em Machu Picchu. 2003. Disponível em www.pauloivo.com.br/peru machupicchu.htm. Acesso em 20 jan 2004
} 
carregadores registrados. Os visitantes precisam ainda ser submetidos a exames sanitários e a orientações de preservação ecológica e histórica.

Dessa forma, as agências de turismo se tornam responsáveis pelo cumprimento das rígidas normas de preservação incluídas no regulamento, devendo assumir a responsabilidade pelas infrações cometidas pelos turistas sob seus cuidados.

Para Lucas (2002), as caminhadas de muitos turistas sobre as ruínas de Machu Picchu pode ter o mesmo impacto que um pequeno terremoto intermitente, chegando a provocar instabilidade no sitio arqueológico. O mesmo alerta é feito pelo guia Juan Diez: "com tanta gente, um dia estas ruínas desabarão"7.

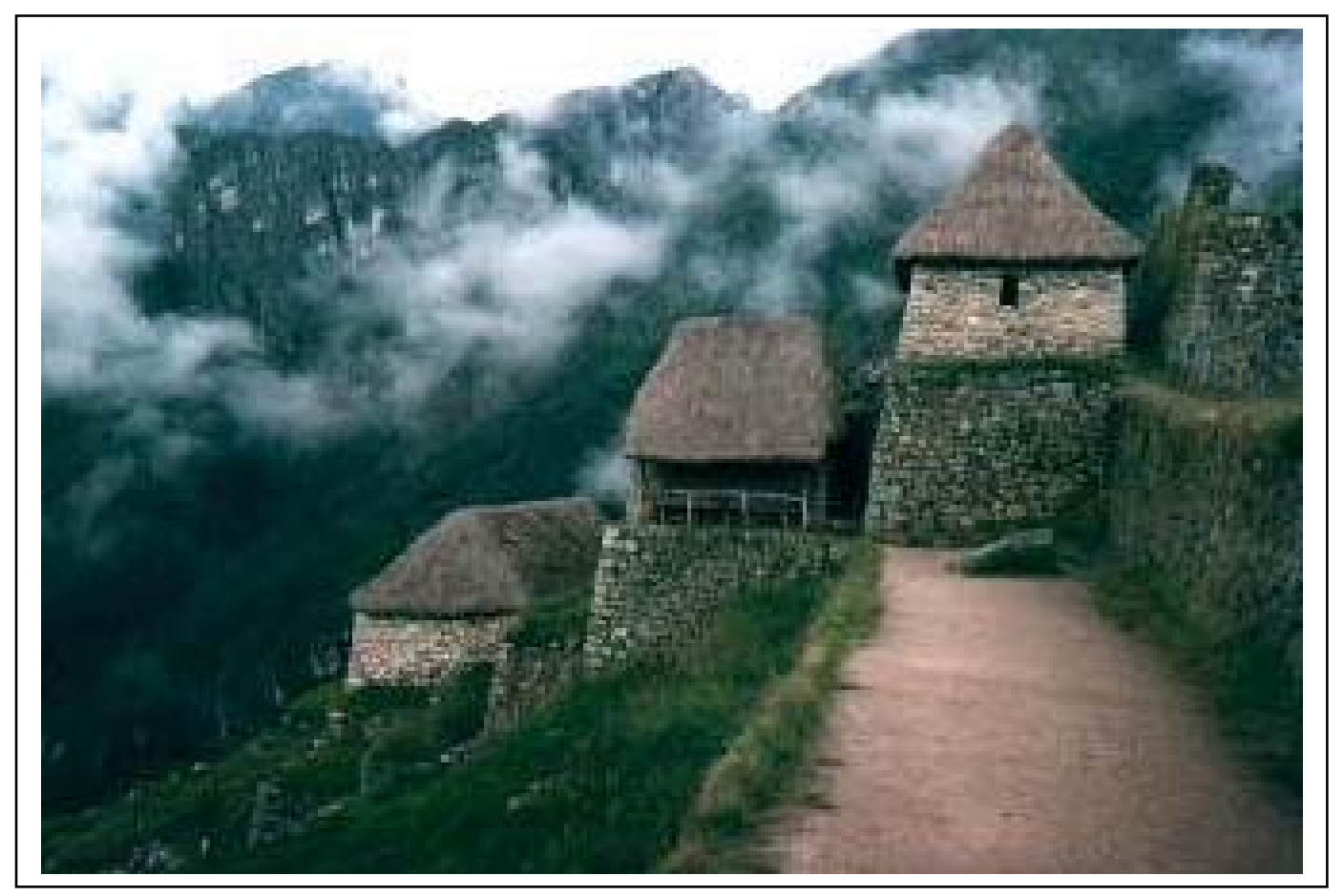

Fonte : Caminho Inca, disponível na internet em < http://www.happydayturismo.com.br/machupicchu >, acesso em: Dezembro 2003.

Verifica-se que a preocupação de Taco é compartilhada por ambientalistas e antropólogos da Universidade Nacional de Cuzco, alarmados diante do excesso de visitantes, o que provoca movimento nas pedras da cidade sagrada. Citam como exemplo um incidente que aconteceu em janeiro de 2000. Uma das pontas 
da pedra principal do relógio solar existente em Machu Picchu quebrou ao cair sobre ela um braço mecânico usado durante as gravações de um comercial publicitário.

O acidente provocou reações por parte de especialistas e ambientalistas. Eles conseguiram que o Instituto Nacional de Cultura do Peru (INC), encarregado de administrar a cidade inca, proibisse a realização, no local, de operações com equipamentos pesados. Ainda cobraram uma posição sobre a exposição do lugar para fins apenas comercias. Os ambientalistas defendem que o sítio deve ser apenas para visitação e apreciação histórica.

Diez lembra que, durante um período, o INC fechou a entrada no Templo do Sol, uma das construções mais relevantes, em razão das pedras estarem sendo danificadas pelos turistas.

Um estudo do Instituto de Prevenção de Desastres da Universidade de Kyoto, do Japão, alertou, em junho de 2001, que o movimento de terra na região desloca as ruínas pré-colombianas um centímetro por mês, o que pode provocar um deslocamento maior, capaz de colocar o conjunto à beira do colapso. A pesquisa diz que uma avalanche pode separar as ruínas em duas partes a qualquer momento.

Machu Picchu e toda a região de Cuzco, se encontram dentro da falha geológica de Tambomachay, que já causou vários sismos ${ }^{8}$.

Para o guia turístico Juan Diez, a falta de normas criteriosas para os passeios pelas ruínas e de controle na quantidade de lixo deixada pelos turistas são de imediato os principais problemas do local.

O guia ainda alerta que, a curto prazo, o governo peruano não têm interesse em organizar o número de turistas em Machu Picchu, calculado em 120 mil turistas por ano ${ }^{9}$. Estão em fase de elaboração, projetos a fim de aumentar o

\footnotetext{
${ }^{7}$ Alerta contido na entrevista concedida a autora da monografia em outubro de 2003, em Machu Picchu. Juan Diez tem graduação superior em História e fala fluentemente o idioma inglês, além do espanhol.

${ }^{8}$ SILVA Fernando.Machu Picchu pede preservação. Disponível em www.Machupicchounesco.net/preservação.html. Acesso em 22 jan 2004.

${ }^{9}$ www.yahoo.com.br
} 
turismo local, que proporcionam maior comodidade aos visitantes. Dessa forma, um maior número de pessoas será atraída ao local com as facilidades para se chegar até as ruínas pelas trilhas.

Um desses projetos é o de instalar um teleférico até as ruínas, que estão situadas a mais de três mil metros de altura. Tal iniciativa permite aumentar de 1.200 para mais de 4 mil o número de visitantes diários. As reações contra a instalação de um teleférico partem tanto de ambientalistas quanto de guias turístico. Para Diez, a iniciativa é uma "loucura", pois irá requerer a realização de uma base de cem metros de profundidade.

Outros projetos em execução estão modificando Águas Calientes, cidadedormitório de acesso a Machu Picchu, onde ficam praticamente todos os hotéis, bares, restaurantes e águas termais. Estão sendo criadas novas ruas, construídos novos hotéis e outros tipos de acomodações estão passando por amplas reformas.

A população de Águas Calientes saltou de 500 para 4 mil pessoas em apenas uma década ${ }^{10}$, representando uma das muitas formas descuidadas como o turismo é administrado na região.

Neste capítulo viu-se a importância de Machu Picchu como Patrimônio Histórico e Cultural da Humanidade e a ameaça do turismo à preservação desse importante sítio arqueológico. No seguinte, analisa-se como unir o turismo e a preservação.

\section{3 - O TURISMO E A PRESERVAÇÃO: COMO UNI-LOS?}

Como foi visto no capitulo anterior, o turismo desordenado em Machu Picchu precisa se reavaliado para não prejudicar irremediavelmente esse Patrimônio da Humanidade. Para tanto, qualquer iniciativa se deve levar em consideração também o planejamento sustentável, resultando assim em um turismo histórico de preservação.

${ }^{10}$ www.yahoo.com.br 
Um turismo que resguarde os patrimônios históricos e culturais da humanidade é visto como sendo uma necessidade absoluta. Para isso, depende dentro de um sério planejamento turístico sustentável.

Para se aliar o turismo, a preservação e o desenvolvimento local, o planejamento sustentável deve levar em conta a preservação da natureza, da cultura, dos processos produtivos locais, da história e seu valor. Ainda precisa adotar uma abordagem que trabalhe a mentalidade da população nativa, os hábitos das organizações turísticas locais e, principalmente, a consciência dos turistas, levando em conta os medos, desejos e necessidades da população local. Estes pontos são fundamentais para que o turismo continue se desenvolvendo em Machu Picchu ao mesmo tempo que a cidade permaneça preservada.

Barreto (2002) afirma que se o desenvolvimento do turismo não for compatível com os objetivos de preservação e cuidados com o patrimônio histórico a ser visitado ou, ainda, se for dominado apenas por interesses econômicos, a sua sustentação será hoje é nula. Se algo não for feito, com o passar dos tempos, não haverá mais sítios históricos e os que restarem estarão depredados e carentes de conservação e cuidados, gerando desinteresse por parte dos turistas.

O autor (Barreto, op. cit.) ainda alerta que, na maioria das vezes, os recursos oriundos do turismo são reinvestidos para atrair ainda mais visitantes e não para a preservação das localidades. Segundo ele, a explicação é de que os objetivos econômicos coletivos de curto prazo tendem a predominar sobre os objetivos de longo prazo. Alerta ainda que o governo peruano só está preocupado com o turista de agora e com o desenvolvimento econômico imediato. Não está pensando no futuro de Machu Picchu, na sua preservação e na perpetuação do turismo.

O referido autor também argumenta que faltam informação e orientação adequadas em Machu Picchu no sentido de estimular a preservação do local por parte dos turistas e envolvê-los nesse compromisso. O mesmo deve ser feito com aqueles que não trabalham diretamente com o turismo, mas se beneficiam dele por estarem perto de um patrimônio da humanidade. 
Para Motta (2002), o envolvimento da comunidade é fundamental para o desenvolvimento sustentado do turismo em Machu Picchu. Deve fazer parte de uma estratégia mais ampla e integrada, que requer ainda sólidas parceiras entre organizações públicas e privadas.

Mesmo em relação ao contexto de rápido crescimento do turismo cultural e histórico de Machu Picchu, a relevância do seu patrimônio histórico e cultural tem se tornado um mecanismo cada vez mais importrante de estímulo a atitudes preservacionistas, tanto por parte dos governos, empreendedores turísticos, comunidades locais e visitantes.

Motta (2002) afirma que chegamos ao século XXI ainda sem uma cultura estabelecida de preocupação e preservação com os patrimônios mundiais, por maior que tenha sido até o momento o esforço em tombar e restaurar conjuntos históricos, delimitar áreas naturais de conservação e proteção e estabelecer parâmetros sustentáveis para o planejamento turístico. O autor considera que, em âmbito mundial, o que se observa é que os padrões de desenvolvimento e de comportamento ainda têm sido mais destrutivos do que preservacionistas.

Segundo Motta (2002), a única chance de reverter esse quadro atual é mobilizar toda a sociedade para a questão da importância da preservação do meio ambiente e as múltiplas identidades e culturas do planeta. Destaca este que não adianta o governo peruano investir em campanhas de preservação ou decretar normas de comportamento em Machu Picchu, se os turistas quando lá chegam agem como se estivessem em um "parque de diversão". Eles "pulam sobre as pedras e construções, escalam os prédios arquitetônicos que estão erguidos e sustentados há séculos pelo tempo e, ainda, futilmente escrevem os seus nomes em pedras milenares dos incas".

A partir da conscientização da importância dos patrimônios históricos para a reconciliação dos interesses de preservação e de desenvolvimento sustentável, outras duas questões também devem ser tema de reflexão: Qual é o espírito do lugar? E como transmiti-lo aos visitantes?

As respostas a essas perguntas são encontradas em grande parte dentro da própria comunidade local, que precisa ser incentivada a resgatá-las em sua 
história oral e documentada. Motta (2002) defende que estimular a população a compreender o sentido do patrimônio é uma forma de criar um compromisso de todos para com a sua sustentação. É ainda dar voz a comunidade, é revelar significados, é provocar emoções e, por fim, é estimular a curiosidade dos turistas e inspirar novas atitudes nos visitantes.

Motta (2002) recomenda ainda aos órgãos de preservação e de turismo ter a prática de envolvimento dos moradores nos levantamentos sobre os inventários culturais e turísticos de suas localidades, dos turistas em suas visitas aos patrimônios históricos e dos governos em seus projetos.

Barreto (2001) observa que os órgãos oficiais de turismo investem exclusivamente na promoção de lugares como destinos turísticos, uma vez que a atividade é dominada por transporte, acomodação e operação. Não se preocupam em estimular a preservação do local para onde os turistas se destinam.

De acordo com o autor, a tarefa de sensibilizar as administrações locais, comerciantes e empresários do setor para o planejamento e desenvolvimento do turismo sustentável é hoje uma tarefa secundária e descontinuada que deveria ser mais amplamente desenvolvida.

Ele conclui que não há, concretamente, um programa conjunto de governos locais e órgãos de preservação para promover o desenvolvimento e a preservação de patrimônios históricos e culturais, como é o caso de Machu Picchu. Barreto (2001) acredita que é urgente e necessária a reciclagem de todos para as novas vocações abertas pelo turismo cultural e histórico. É preciso direcionar investimentos do setor para campanhas e serviços de preservação, a fim de garantir que gerações futuras possam conhecer o valor da sua história por meios do turismo. 


\section{4 - O TURISMO DE BRASILEIROS EM MACHU PICCHU}

\subsection{Estatística de turistas brasileiros e europeus}

O Peru é o terceiro maior país da América do Sul e ocupa uma área de 1.285.216 quilômetros quadrados. Tem 25.662.000 habitantes $^{11}$. Sua principal atração turística é a cidade de Cuzco, seguida de Machu Picchu.

Os europeus são os maiores visitantes de ambas as cidades peruanas ${ }^{12}$. Depois, são os turistas da própria América do Sul, principalmente do Brasil, Argentina e Bolívia, não respectivamente nessa ordem. Os dados oficiais do governo do Peru incluem esses três países na mesma estatística. Portanto, não há como separá-los. O mesmo ocorre com os países da Europa, ou seja, são registrados como um único contingente de turistas.

Número de turistas em Machu Picchu e Cuzco

\begin{tabular}{|l|l|l|l|}
\hline$N^{\circ}$ turistas & ORIGEM & ANO & TOTAL \\
\hline 49.000 & Brasil/Argentina/Bolívia & 1996 & 84.000 \\
25.000 & Europa & & \\
10.000 & Outros & 1997 & 89.000 \\
\hline 35.000 & Brasil & & \\
30.000 & Europa & 1998 & 90.000 \\
24.000 & Outros & & \\
\hline 28.000 & Brasil & & 97.000 \\
40.000 & Europa & 1999 & \\
22.000 & Outros & & 105.000 \\
\hline 45.000 & Brasil/Argentina/Bolívia & 2000 & \\
20.000 & Europa & & 119.000 \\
32.000 & Outros & & \\
\hline 48.000 & Europa & 2001 & \\
39.000 & Brasil/Argentina/Bolívia & & \\
15.000 & Outros & 2002 & \\
\hline 56.000 & Europa & & \\
24.000 & Brasil & & \\
39.000 & Outros & & \\
\hline 52.000 & Europa & & \\
38.000 & Outros & & \\
23.000 & Brasil & & \\
\hline
\end{tabular}

Fonte: http://embperu.org.br/consulpr.htm

\footnotetext{
11 Informação disponível na página eletrônica do Governo do Peru (http://www.peru.org.pe)

${ }^{12}$ Os dados estatísticos disponíveis sobre número de turistas incluem Machu Picchu e Cuzco. Não podem ser separados. De acordo com o guia peruano Juan Diez e informações na página eletrônica do Governo do Peru (http://www.peru.org.pe), os turistas estrangeiros visitam em uma única viagem ambas as cidades.
} 
Pela tabela acima, verifica-se que turistas brasileiros, argentinos e bolivianos eram em maior número nos anos de 1996, 1997 e 1999. A partir de 2000, o quadro se reverteu. Até o ano de 2002, última estatística oficial do governo peruano, os visitantes europeus foram em quantidade superior.

Para o guia peruano Juan Diez ${ }^{13}$, a instabilidade econômica dos países da América do Sul espantou os turistas. "Hoje, os europeus chegam em grande número, principalmente alemães e franceses". Diez afirma que há também muitos turistas americanos e japoneses. No entanto, eles não constam dos dados oficiais disponibilizados pelo governo do Peru em seu portal eletrônico ${ }^{14}$.

Em 2000, o percentual de turistas europeus representou 47\% do total de 102 mil visitantes. Já o de brasileiros foi de $38 \%$.

No ano de 2001, o número de europeus permaneceu o mesmo (47\%), enquanto o de brasileiros caiu 20\%. Em 2002, o percentual ficou o mesmo: 46\% de europeus e $20 \%$ de brasileiros.

\subsection{Turistas brasilienses em Machu Picchu}

Ao fazer um recorte para o número de turistas do Distrito Federal que viajam para Machu Picchu, utiliza-se como referência básica os dados fornecidos pela agência de Turismo Weekend ${ }^{15}$. De acordo com o guia Eduardo Dutra ${ }^{16}$, as visitas por parte dos brasilienses vêm crescendo desde 1998. Ele atribui esse aumento ao fato de Brasília ser uma cidade também voltada para o misticismo, como a de Machu Pichu.

Segundo Dutra, em 1998, a Weekend fechou pacotes turísticos para a cidade Inca com 159 brasilienses; em 1999, 240; em 2000, 310; e, 2001, 393; em 2002, 449; e 2003, 510 pessoas.

\footnotetext{
${ }^{13}$ Entrevista concedida a autora da monografia em outubro de 2003, durante viagem a Machu Picchu e Cuzco.

14 http://www. peru.org.pe

${ }^{15}$ A Agência Weekend está localizada na SCLN 313 Bloco 62, Brasília - DF.

${ }^{16}$ Os dados foram repassados em 30/01/04.
} 
Ao comparar os anos de 1998 e 2003, observa-se que houve um crescimento de $220 \%$ pela procura de viagens para Machu Picchu somente em uma agência de Turismo. Para Dutra, tal constatação deve ser representativa ao número de visitantes do Distrito Federal. Ele explica que, no Centro-Oeste, só há 4 agências especializadas em pacotes para Machu Picchu. Ressalta ainda que, no total, no Brasil, são 114 agências que fazem o circuito da trilha Inca, sendo 38 em São Paulo; 28, no Rio de Janeiro; 13 em outros estados da região Sudeste; 19, da região Sul; 7, do Nordeste; 5, do Norte; e ainda as 4 do Centro-Oeste.

Outras 700 agências brasileiras levam turistas até Lima, no Peru, e de lá eles mesmo embarcam rumo a Machu Picchu. Nesse percentual, não estão incluídos os visitantes que compram passagens aéreas diretamente para Cuzco, de onde saem acompanhados de guias locais para a cidade Inca.

Em uma consulta a outra agência brasiliense - Abrolhos Turismo ${ }^{17}$ verificou-se que, somente em 2003, ela embarcou 500 pessoas para a cidade Inca. Esse é o único dado exato disponível, conforme o responsável pela agência, Fernando Ribeiro, mas é quase identico ao da outra agência.

Um dado complementar também pode ser a impressão dos turistas que foram ao local. Observando-os e entre conversas fica evidente que mesmo esta autora também ficou com estas impressões, mas como estava focada no turismo, pode concluir mais : é urgente o planejamento para a sustentabilidade do local e a sua preservação histórica. 


\section{Considerações Finais}

Pelo presente estudo, verifica-se que o desenvolvimento sustentado do turismo cultural e histórico em Machu Picchu ainda é um longo caminho a ser trilhado que depende de inúmeros fatores.

Um deles é a capacidade do desenvolvimento turístico integrado com as atrações históricas, capaz de oferecer roteiros que possam beneficiar não somente o visitante e o aspecto econômico da região, mas também a da preservação desse belo e misterioso patrimônio.

O turismo pode ser um importante instrumento na gestão de sítios históricos e para o desenvolvimento local de cidades como Machu Picchu, desde que haja conscientização por parte de todos - governos, turistas, empresários e comunidade - com relação à conservação cultural do lugar.

O turismo voltado para a preservação histórica traz inúmeras vantagens. Diversifica, aumenta e torna permanente as atrações culturais e históricas de determinada localidade; incentiva oportunidades de aprendizagem informal no campo da educação histórica, cultural e patrimonial; orienta os fluxos de visitação, protegendo ambientes frágeis; e proporciona um instrumental de planejamento em parceria com a comunidade, os governos e os turistas. Portanto, pode ser muito importante para o desenvolvimento local.

No entanto, o excesso de visitantes em Machu Picchu poderá comprometer seriamente o conjunto histórico. Mesmo com a recomendação da Unesco de reduzir as visitas diárias para 500 pessoas, o Instituto Nacional de Cultura do Peru pouco vez para controlar o turismo desordenado. Tal atitude demonstra que a maior preocupação é aumentar o número de pessoas e a arrecadação econômica, em detrimento da conservação histórica e cultural do local.

O desenvolvimento do turismo histórico, como o de Machu Picchu, depende também da capacidade dos órgãos públicos e instituições de

\footnotetext{
${ }^{17}$ A agência Abrolhos Turismo fica localizada no SGAS 902 Loja 18, Edifício Athenas Asa Sul, Brasília-DF.
} 
preservação de estruturarem programas que envolvam todo o conjunto da sociedade civil.

A meca dos místicos atrai turistas do mundo inteiro. No caso específico dos brasileiros, conclui-se que o percentual de $20 \%$ de visitas anuais a Machu Picchu é relativamente considerável em relação a outros países da América do Sul. Só perde para a Argentina, que recebe 34\% de turistas do Brasil por ano, e para a fronteira do Paraguai, para onde se dirigem os "sacoleiros" brasileiros.

Brasília, pela sua característica mística, também embarca um bom número de visitantes anualmente a Machu Picchu. O percentual vem crescendo a cada ano e a tendência é se consolidar no roteiro de viagens dos brasilienses.

Esta pesquisadora é um exemplo dessa constatação, que esteve no conjunto histórico em outubro de 2003, buscando inspiração e informações para esta monografia. A energia da cidade Inca foi tão intensa que foi estímulo definitivo para realizar sua monografia, centrada na importância da preservação de Machu Picchu para toda a humanidade e sua relação com Brasília: inicialmente para identificar o fluxo turístico naquela direção, mas houve transformações fortalecendo e direcionando o interesse por este tipo de turismo.

No futuro, pretendo analisar o turismo histórico e místico em nossa cidade, tendo como foco lutar para que os problemas de Machu Picchu não aconteçam aqui em Brasília. A educação ambiental para o turismo, além de informações mais consistentes sobre o local, também são aspectos fundamentais para a melhoria dos padrões turísticos. 


\section{REFERÊNCIAS BIBLIOGRÁFICAS}

ARANTES, Antonio. Produzindo o passado: estratégias de construção do patrimônio cultural. 1984.

BARRETO, Margarita. Turismo e legado Cultural. Campinas: Papirus, 2001

BO, Proteção do Patrimônio na Unesco. Brasília: Unesco, 2003.

CANES, Roberto. Surge Machu Picchu. 2002. Disponível em http://www.estadao.com.br/turismo/noticias/2004/jan.htm. Acesso em 26 jan 2004.

CASTRO, Sonia. O Estado na preservação de bens culturais: o tombamento. 1991.

CHAUÍ, C. A cidade perdida. São Paulo: Editorial, 2002.

CEZARE, Vilma. Machu Picchu: a cidade Perdida. Disponível em http://www.machupiccuanalise.net/ecoturimo.html. Acesso em 22 jan 2004.

DEVERRO, Paulo. A ameaça em Machu Picchu. 2003. Disponível em http://www.pauloivo.com.br/peru machupicchu.htm. Acesso em 20 jan 2004.

HALBWACHS, M. A memória coletiva. São Paulo: Vértice, 1990.

LEMOS, M. O que é patrimônio histórico. São Paulo: Ediouro, 1985.

LUCAS, Kintto. Machu Picchu a beira de um colapso. Disponível em http://www.tierramerica.net/2002/0428/particulo.shtml Acesso em 21 jan 2004.

MOTTA, Sérgio. Machu Picchu: na trilha da aventura. São Paulo: Ediouro, 2002.

RIBERI, Silveira. A cidade perdida. 2.000. Disponível em http://www.arquitectum.com/cinternacional/portugues.htm. Acesso em 19 jan 2004.

RODRIGUES, José Eduardo R. Patrimônio Cultural: análise de alguns aspectos polêmicos. Revista de Direito Ambiental. São Paulo: Revista dos Tribunais, 2.001. jan/mar. 21.

SANTOS, S. Surge Machu Picchu. São Paulo: Editorial, 2002

SILVA, Fernando. Machu Picchu pede preservação. Disponível em http://www.Machupicchounesco.net/preservação.html. Acesso em 22 jan 2004.

SOARES, Léo. Cuzco: o umbigo do mundo. 2.003. Disponível em http://www.terramistica.com.br/index.php?add=Artigos.html. Acesso em 19 jan 2004.

TELLES, Augusto C. da Silva. Centros históricos: notas sobre a política brasileira de preservação. Revista do Patrimônio Histórico e Artístico Nacional. Brasília, $\mathrm{n}^{\circ}$ 19, 1984. 


\section{Páginas eletrônicas consultadas}

http://www.embperu.org.br

http://www.peru.org.pe

http://www.traficoperu.com

http://ww.terra.com.br/turismo

http://www.yahoo.com.br/turismo

http://www.descubrasuaamerica.hpg.ig.com.br

http://www.revistaviagem.com.br

http://www1.folha.uol.com.br/folha/mundo/ult9421279.shl

http://www1.folha.uol.com.br/folha/ciencia/ult306u2858.shtml

http://www.copacabana.com/r-republ.shtml

http://www.rotaciclistica.com.br/projetobrasilperu/peru.asp

http://www.senaiturismo.com.br/site/noticias. php?cod=674

\section{Entrevista pessoal}

Juan Diez, guia turístico em Machu Picchu, concedida em outubro de 2.003.

\section{Entrevistas por e-mail}

\section{Eduardo Dutra}

Guia da agência Weekend

SCLN 313 Bloco 62 - Asa Norte

Fernando Ribeiro

Proprietário da agência Abrolhos de Turismo

SGAS 902 Loja 18 - Asa Sul 


\section{Agências de viagens consultadas por e-mail}

Bom Destino (SP)

Pisa Trenig "especializada em viagens para Machu Picchu” - São Paulo

LM - Agência do Gilberto Salomão - Lago Sul - Brasília

Informações culturais

Embaixada do Peru (sr. Oscar Levano, adido Cultural)

Setor de Embaixadas Sul - Avenida da Nações Quadra 811 Lote 43

Brasília, DF

Telefone: (61) 242.9933

Endereço eletrônico: http://www.embperu@embperu.org.br 


\section{Anexo :}

Há muita falta de informações para os turistas que viajam rumo a Machu Picchu. Esta pesquisadora elaborou um roteiro de orientações a ser enviado a algumas agências de turismo brasileiras. São simples e importantes sugestões para os visitantes.

1) Nunca saia sem um guia;

2) Deve-se andar devagar (despacito) sem fazer muito esforço em razão da alta altitude;

3) No caso de se sentir mal por causa da altitude, recomenda-se tomar um comprimido de "Coramina";

4) Deve-se passar repelente em todo o corpo, pois tanto em Machu Picchu como Aguas Calientes os mosquitos são terríveis;

5) Recomenda-se tomar o chá de coca devido à altitude;

6) A conversão para a moeda local deve ser feita em uma casa de câmbio oficial. Em outros locais, há risco de adulteração nas máquinas de calcular;

7) O clima é muito seco e frio. Portanto, é necessário passar bastante creme no corpo e hidratante nos lábios;

8) Antes da viagem, é importante obter informações sobre o local, disponíveis em livros, reportagens e páginas eletrônicas especializadas. Tal dica vale para viagens a qualquer País. Sugestões:

http://www.embperu.org.br;

http://www.peru.org.pe;

http://www.traficoperu.com;

http://ww.terra.com.br/turismo;

http://www.yahoo.com.br/turismo;

http://www.descubrasuaamerica.hpg.ig.com.br;

http://www.revistaviagem.com.br;

http://www1.folha.uol.com.br/folha/mundo/ult9421279.shl 
9) Não comer nas ruas, somente em restaurantes;

10) Não comer muito à noite;

11) Conhecer o Pisac (o melhor mercado popular) que oferece muita variedade e bons preços;

12) Prestar atenção ao escolher os hotéis. Nem todos possuem suítes;

13) Pedir sempre descontos ao fazer compras.

\section{Dicas Gastronômicas:}

1) Um dos principais pratos peruano é o Cevice, um peixe cru marinado ao suco de limão, alho e cebola. É imperdível;

2) Não deixe de experimentar as saborosas trutas peruanas;

3) A mais famosa bebida local é o Pisco, um aguardente de uva. É utilizado no coquetel Posco Sour, feito a base de limão, clara de ovo e gotas de angostura.

4) O refrigerante INKA Cola, feito de milho, é o preferido dos peruanos. Eles o tomam natural, sem gelo. 


\section{9 - Ilustrações de Machu Picchu}

Abaixo estão as fotos da viagem a Machu Picchu, tiradas pela pesquisadora em outubro de 2003
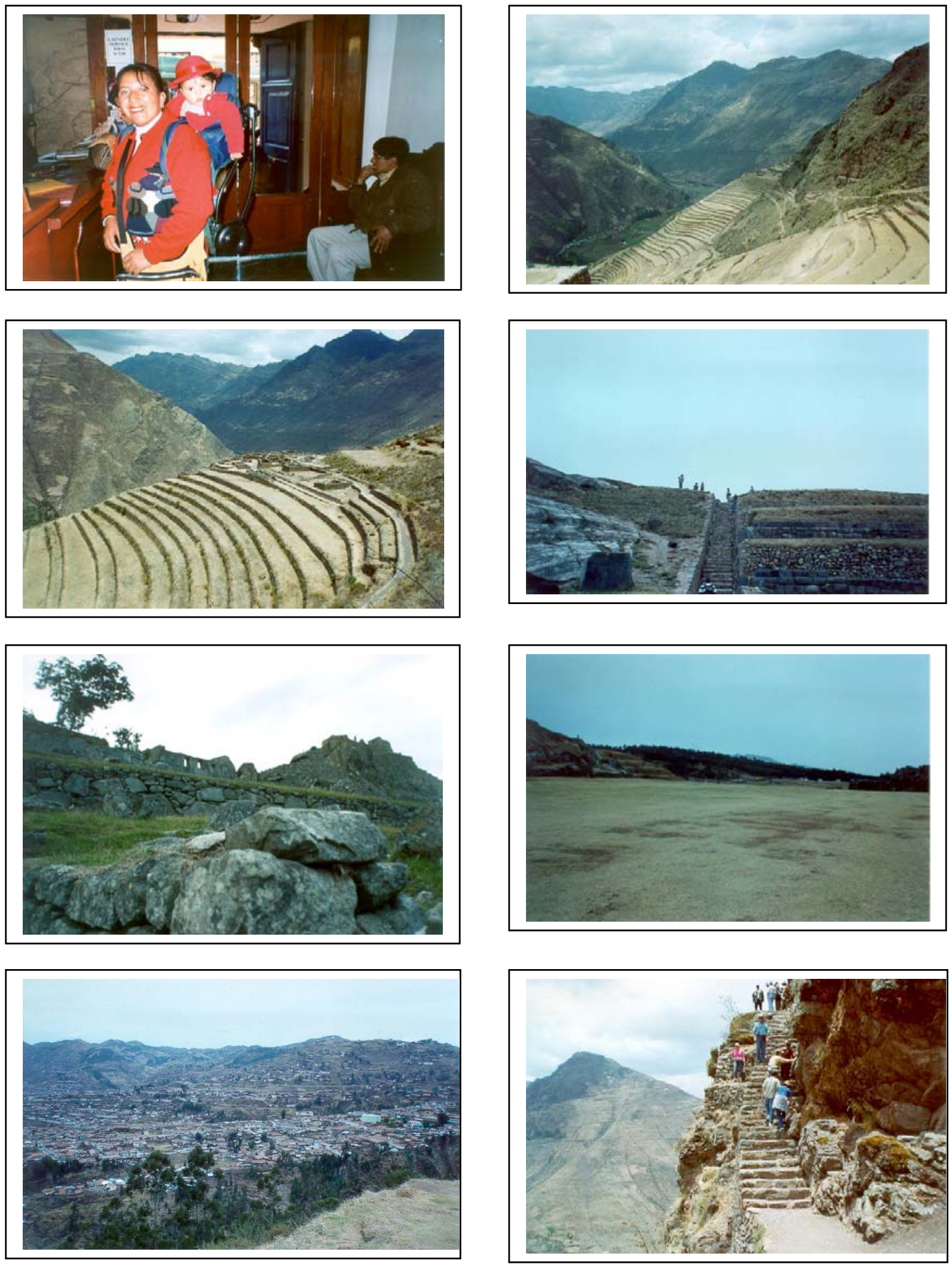